\title{
Satellite microwave assessment of Northern Hemisphere lake ice phenology from 2002 to 2015
}

\author{
Jinyang Du ${ }^{1}$, John S. Kimball ${ }^{1}$, Claude Duguay ${ }^{2}$, Youngwook Kim ${ }^{1}$, and Jennifer D. Watts ${ }^{1}$ \\ ${ }^{1}$ Numerical Terradynamic Simulation Group, College of Forestry \& Conservation, University of Montana, \\ Missoula, MT 59812, USA \\ ${ }^{2}$ Department of Geography \& Environmental Management and Interdisciplinary Centre on Climate Change, \\ University of Waterloo, Waterloo, Ontario N2L 3G1, Canada \\ Correspondence to: Jinyang Du (jinyang.du@ ntsg.umt.edu)
}

Received: 18 August 2016 - Published in The Cryosphere Discuss.: 5 September 2016

Revised: 1 December 2016 - Accepted: 13 December 2016 - Published: 12 January 2017

\begin{abstract}
A new automated method enabling consistent satellite assessment of seasonal lake ice phenology at $5 \mathrm{~km}$ resolution was developed for all lake pixels (water coverage $\geq 90 \%$ ) in the Northern Hemisphere using $36.5 \mathrm{GHz}$ H-polarized brightness temperature $\left(T_{\mathrm{b}}\right)$ observations from the Advanced Microwave Scanning Radiometer for EOS and Advanced Microwave Scanning Radiometer 2 (AMSR-E/2) sensors. The lake phenology metrics include seasonal timing and duration of annual ice cover. A moving $t$ test (MTT) algorithm allows for automated lake ice retrievals with daily temporal fidelity and $5 \mathrm{~km}$ resolution gridding. The resulting ice phenology record shows strong agreement with available ground-based observations from the Global Lake and River Ice Phenology Database (95.4\% temporal agreement) and favorable correlations $(R)$ with alternative ice phenology records from the Interactive Multisensor Snow and Ice Mapping System ( $R=0.84$ for water clear of ice (WCI) dates; $R=0.41$ for complete freeze over (CFO) dates) and Canadian Ice Service ( $R=0.86$ for WCI dates; $R=0.69$ for CFO dates). Analysis of the resulting 12-year (20022015) AMSR-E/2 ice record indicates increasingly shorter ice cover duration for 43 out of $71(60.6 \%)$ Northern Hemisphere lakes examined, with significant $(p<0.05)$ regional trends toward earlier ice melting for only five lakes. Higherlatitude lakes reveal more widespread and larger trends toward shorter ice cover duration than lower-latitude lakes, consistent with enhanced polar warming. This study documents a new satellite-based approach for rapid assessment and regional monitoring of seasonal ice cover changes
\end{abstract}

over large lakes, with resulting accuracy suitable for global change studies.

\section{Introduction}

Ice phenology describes the seasonal cycle of lake ice cover and encompasses freeze-up and breakup periods and ice cover duration (Duguay et al., 2015a). Freeze-up corresponds to the time period between the beginning of ice formation and the formation of a complete sheet of ice; breakup involves the time period between the onset of spring melt and the complete disappearance of ice from the lake surface (Kang et al., 2012). These ice phenology variables are key metrics sensitive to weather and climate conditions and influence lakeatmosphere interactions and hydrological and ecological processes in high-latitude and high-altitude regions (Duguay et al., 2006, 2012, 2015a; Mishra et al., 2011). By insulating lake water from the overlying atmosphere and minimizing water and atmosphere heat and gas exchanges, lake ice has a controlling influence on water-column oxygen concentration, water temperature, and the composition and abundance of aquatic species (Livingstone, 1997; Bengtsson and Herschy, 2012; Kang et al., 2012; Wrona et al., 2016). In addition to the impacts on aquatic life, the formation and disappearance of lake ice also has a significant influence on the spread of man-made pollutants such as perfluorinated chemicals (PFCs) (Veillette et al., 2012; Wrona et al., 2016). The extent and duration of lake ice also affect human activities, including hydroelectric power generation, navigation 
and winter transportation, and production and distribution of food and water (Schröter et al., 2005; Weyhenmeyer et al., 2011). Moreover, lake ice phenology is closely coupled with atmospheric heat fluxes (Latifovic and Pouliot, 2007; Park et al., 2016) and sensitive to the alteration of weather patterns under projected global warming (Magnuson et al., 2000).

Accurate and consistent records of lake ice phenology especially in data-sparse regions, including much of the panArctic and Qinghai-Tibetan Plateau regions, provide valuable information for monitoring global change impacts on high-latitude and high-altitude environments (Magnuson et al., 2000). Previous studies have documented significantly earlier ice breakup between the 1950s and 2000s for lakes in Canada (Duguay et al., 2006; Latifovic and Pouliot, 2007; Prowse et al., 2011) and decreasing ice cover duration of Eurasia lakes during the last few decades (Vuglinsky and Gronskaya, 2006; Karetnikov and Naumenko, 2008; Prowse et al., 2011). Shorter ice cover seasons may promote greater $\mathrm{CH}_{4}$ emissions from northern lakes (Greene et al., 2014), which could reinforce further climate warming due to the role of $\mathrm{CH}_{4}$ as a potent greenhouse gas. Despite a general tendency for later freezing and earlier breakup in the Northern Hemisphere (Magnuson et al., 2000), various tendencies including earlier ice formation and later ice breakup over specific lakes and time periods may exist. For example, observations from satellite altimetry and radiometry over 1992-2004 for Lake Baikal showed a tendency for colder winters, with earlier ice formation, later ice breakup, and ice duration increase (Kouraev et al., 2007a, b).

A historic lake ice phenology database has been assembled from long-term ground-based observations across the northern domain (Magnuson et al., 2000; Benson et al., 2012); however, the number of monitoring sites is extremely sparse, with variable observational recording periods and methods, which limits capabilities for regional assessment and monitoring of environmental changes. Data acquired from spaceborne optical-thermal infrared (TIR) and microwave sensors have also been applied for monitoring river and lake ice phenology at regional and global scales (Chu and Lindenschmidt, 2016). Optical-TIR remote sensing can provide accurate estimation of land surface temperature (LST) and classification of land cover types at relatively fine spatial resolutions ( $\sim 10$ s to 100 s of meters $),$ while LST ( $1 \mathrm{~km}$ resolution) and snow cover $(500 \mathrm{~m}$ resolution) products derived from MODIS (Moderate Resolution Imaging Spectroradiometer) have been used to infer lake ice conditions (Nonaka et al., 2007; Hall et al., 2010; Kheyrollah Pour et al., 2012). Time series of AVHRR (Advanced Very High Resolution Radiometer) imagery have also been used to classify Canadian lake ice phenology events with relatively high accuracy (Latifovic and Pouliot, 2007). However, regional monitoring of lake ice dynamics from satellite optical-TIR sensors is constrained by signal degradation and data loss stemming from seasonal reductions in solar illumination at higher latitudes and persistent cloud cover, smoke, and other atmospheric aerosol contamination (Maslanik and Barry, 1987; Jeffries et al., 2005; Helfrich et al., 2007; Kang et al., 2012).

Satellite microwave remote sensing at lower frequencies $(\sim<89 \mathrm{GHz})$ is relatively insensitive to solar illumination and atmosphere constraints, while current microwave radiometers onboard polar orbiting satellites provide frequent ( $\sim$ daily) observations spanning northern $\left(\geq 45^{\circ} \mathrm{N}\right)$ land areas. The active and passive microwave retrievals are also highly sensitive to the large contrast in surface dielectric properties between open water and ice cover over large lakes. Despite successful applications using active microwave remote sensing in lake ice retrieval (Leconte and Klassen, 1991; Nolan et al., 2002; Howell et al., 2009; Geldsetzer et al., 2010), capabilities for global lake ice monitoring from satellite radar sensors have been constrained by limited global coverage and temporal frequency of observations. Alternatively, spaceborne microwave radiometers have provided brightness temperature $\left(T_{\mathrm{b}}\right)$ observations since 1978 with relatively high temporal fidelity ( $\sim 1-2$ days) especially at higher $\left(\geq 45^{\circ} \mathrm{N}\right)$ latitudes. Frequent microwave radiometer data acquisition and complete time series of images are valuable to ice phenology studies and also supportive to improving numerical weather model predictions (Helfrich et al., 2007) and timely monitoring of lake ice events, including transient ice disturbances (Jeffries et al., 2005). Despite having relatively coarser spatial resolution retrievals than optical-TIR sensors, the capability for consistent daily lake ice monitoring available from passive microwave observations provides added precision for delineating lake ice phenology trends, which may be much smaller than year-to-year ice cover variability. The satellite $T_{\mathrm{b}}$ retrievals are capable of detecting lake ice phenology events coinciding with large changes in surface emissivity, but the passive microwave retrievals are constrained by a generally coarser spatial resolution than radar and optical-TIR sensors. Despite these limitations, ice freeze-up and breakup events for Great Slave Lake (GSL) were monitored using a threshold-based method for SSM/I (Special Sensor Microwave Imager) observations at $85 \mathrm{GHz}$ (Walker and Davey, 1993; Ménard et al., 2002). Recently, H-polarized AMSR-E (Advanced Microwave Scanning Radiometer for EOS) $T_{\mathrm{b}}$ observations at $19 \mathrm{GHz}$ were analyzed to determine ice phenology for GSL and Great Bear Lake (GBL), the two largest lakes in northern Canada (Kang et al., 2012, 2014). Similar $T_{\mathrm{b}}$ records from SSM/I and SMMR (Scanning Multichannel Microwave Radiometer) were also used to monitor lake ice phenology for Nam Co Lake (Ke et al., 2013) and Qinghai Lake (Che et al., 2009) within the high-elevation Qinghai-Tibetan Plateau. Previous studies based on satellite passive microwave remote sensing have mainly focused on one or two lakes using empirical algorithm thresholds developed for specific study areas. There is a great need to develop a universal lake ice detection algorithm and establish a consistent ice phenology database covering major lakes at the global scale for climate impact 
assessments such as those published by the Intergovernmental Panel and Climate Change (Stocker et al., 2013).

In this study, we present a new automated method to derive lake ice phenology using $36.5 \mathrm{GHz} \mathrm{H}$-polarized satellite radiometric $T_{\mathrm{b}}$ measurements from AMSR-E and AMSR2 (Advanced Microwave Scanning Radiometer 2). The algorithm is used to produce daily lake ice maps with $5 \mathrm{~km}$ gridding. The resulting AMSR-E/2 Lake Ice Phenology (LIP) record encompasses all $5 \mathrm{~km}$ by $5 \mathrm{~km}$ lake pixels (water coverage $\geq 90 \%)$ within the Northern Hemisphere $\left(\geq 0^{\circ} \mathrm{N}\right)$ and spans more than 12 years of observations including both AMSR-E (June 2002 to September 2011) and AMSR2 (June 2012 to December 2015) satellite sensor records. Here we present a detailed methods description and evaluation of the LIP product against other independent observations and alternative lake ice products. A trend analysis is also conducted to characterize recent regional LIP changes over the study period.

\section{Methods}

\subsection{Study domain and datasets}

\subsubsection{Study domain}

This study utilizes satellite passive microwave remote sensing to detect lake ice changes for $5 \mathrm{~km}$ lake pixels in the Northern Hemisphere, with a particular focus on lake ice phenology in the mid- and high latitudes $\left(\geq 30^{\circ} \mathrm{N}\right)$. The domain (Fig. 1) includes the high northern pan-Arctic region and high-altitude Qinghai-Tibetan Plateau, which are data-sparse but strongly sensitive to the Arctic amplification effect (Serreze and Francis, 2006; Woo et al., 2007) and/or elevation-dependent warming (Wang et al., 2011; Mountain Research Initiative EDW Working Group, 2015). Both regions are also characterized by cold climate conditions with extensive winter ice cover. The resulting domain includes three sets of lakes for algorithm evaluation and lake ice phenology analysis. Among the lakes analyzed, four are represented in the Global Lake and River Ice Phenology Database (GLRIPD) (Benson and Magnuson, 2000) and were used to evaluate the LIP estimates on a per pixel basis against available ground-based observations; the four GLRIPD lakes evaluated include Lake Superior in the USA and Canada and Lake Oulujarvi, Lake Haukivesi, and Lake Paijanne in Finland. In addition, 12 North American lakes (GBL, GSL, Smallwood Lake, Nettiling Lake, Dubawnt Lake, Amadjuak Lake, Wollaston Lake, Baker Lake, Kasba Lake, Lesser Slave Lake, and Peter Pond Lake in Canada and Red Lake in USA) that experience annual breakup and freeze-up events were selected for lake-wide intercomparisons between the LIP metrics derived from this study and alternative lake ice products from the Interactive Multisensor Snow and Ice Mapping System (IMS) (Helfrich et al., 2007; http://www.natice.noaa.gov/ims/) and the Canadian Ice Service (CIS) (Howell et al., 2009).

Finally, regional LIP trends were assessed over the 12-year (2002-2015) satellite record for 71 Northern Hemisphere lakes identified in the Global Lakes and Wetlands Database (GLWD) (Lehner and Döll, 2004). The lakes selected represent approximately $23 \%\left(297044 \mathrm{~km}^{2}\right)$ of the estimated total surface area of large lakes ( $\operatorname{area} \geq 50 \mathrm{~km}^{2}$ ) within the domain (Lehner and Döll, 2004). The 71 lakes were selected on the basis of having (a) at least one $5 \mathrm{~km}$ lake pixel with $100 \%$ water coverage and located outside of a $5 \mathrm{~km}$ land buffer zone and (b) all pixels representing the lake having at least 20 days with full ice coverage and 20 days with open water. Criterion (a) was used to reduce potential contamination from adjacent land areas since the native resolutions of $36.5 \mathrm{GHz}$ observations are approximately $14 \mathrm{~km} \times 8 \mathrm{~km}$ for AMSR-E and $12 \mathrm{~km} \times 7 \mathrm{~km}$ for AMSR2, respectively (Imaoka et al., 2010). Criterion (b) emphasizes lakes having extended ice and open water seasons rather than those with a temporary ice cover or short open water phase. The 20-day minimum duration was set according to the predefined subsample sizes of our algorithm (Sect. 2.3).

\subsubsection{Datasets used for algorithm development}

The lake ice detection algorithm developed in this study relies primarily on $36.5 \mathrm{GHz} \mathrm{H}$-polarized $T_{\mathrm{b}}$ retrievals from AMSR-E and AMSR2. The AMSR-E sensor was operational on the NASA Aqua satellite from June 2002 to October 2011 and provided twice-daily measurements of global microwave emissions over land with descending/ascending orbital equatorial crossings at 01:30/13:30 local time and vertically $(\mathrm{V})$ and horizontally $(\mathrm{H})$ polarized $T_{\mathrm{b}}$ retrievals at six frequencies $(6.9,10.7,18.7,23.8,36.5,89.0 \mathrm{GHz})$. For this study, we used the AMSR-E ascending $36.5 \mathrm{GHz}$ orbital swath data at the native footprint resolution of approximately $14 \mathrm{~km} \times 8 \mathrm{~km}$ (Kawanishi et al., 2003). After the cessation of AMSR-E operations on 4 October 2011, its successor AMSR2 was launched on 18 May 2012 onboard the sunsynchronous JAXA GCOM-W1 satellite. AMSR2 is similar to AMSR-E in sensor configuration, including frequencies, incidence angle, and orbital equatorial crossing time. Major AMSR2 advancements over AMSR-E include an additional frequency at $7.3 \mathrm{GHz}$ designed for mitigating radio frequency interference (RFI) and a larger (2.0 m diameter) main reflector for enhanced spatial resolution. The AMSR2 L1R (version 1.2) resampled ascending swath $36.5 \mathrm{GHz} T_{\mathrm{b}}$ retrievals at approximately $12 \mathrm{~km} \times 7 \mathrm{~km}$ resolution were used for this study. The uncalibrated AMSR2 $T_{\mathrm{b}}$ retrievals were estimated to be positively biased against AMSR-E by $\sim 1.3 \mathrm{~K}$ (Du et al., 2014). However, the sensor inconsistency is expected to have minimal impacts on our algorithm, which relies on $T_{\mathrm{b}}$ time series change signal detection rather than $T_{\mathrm{b}}$ absolute accuracy. 


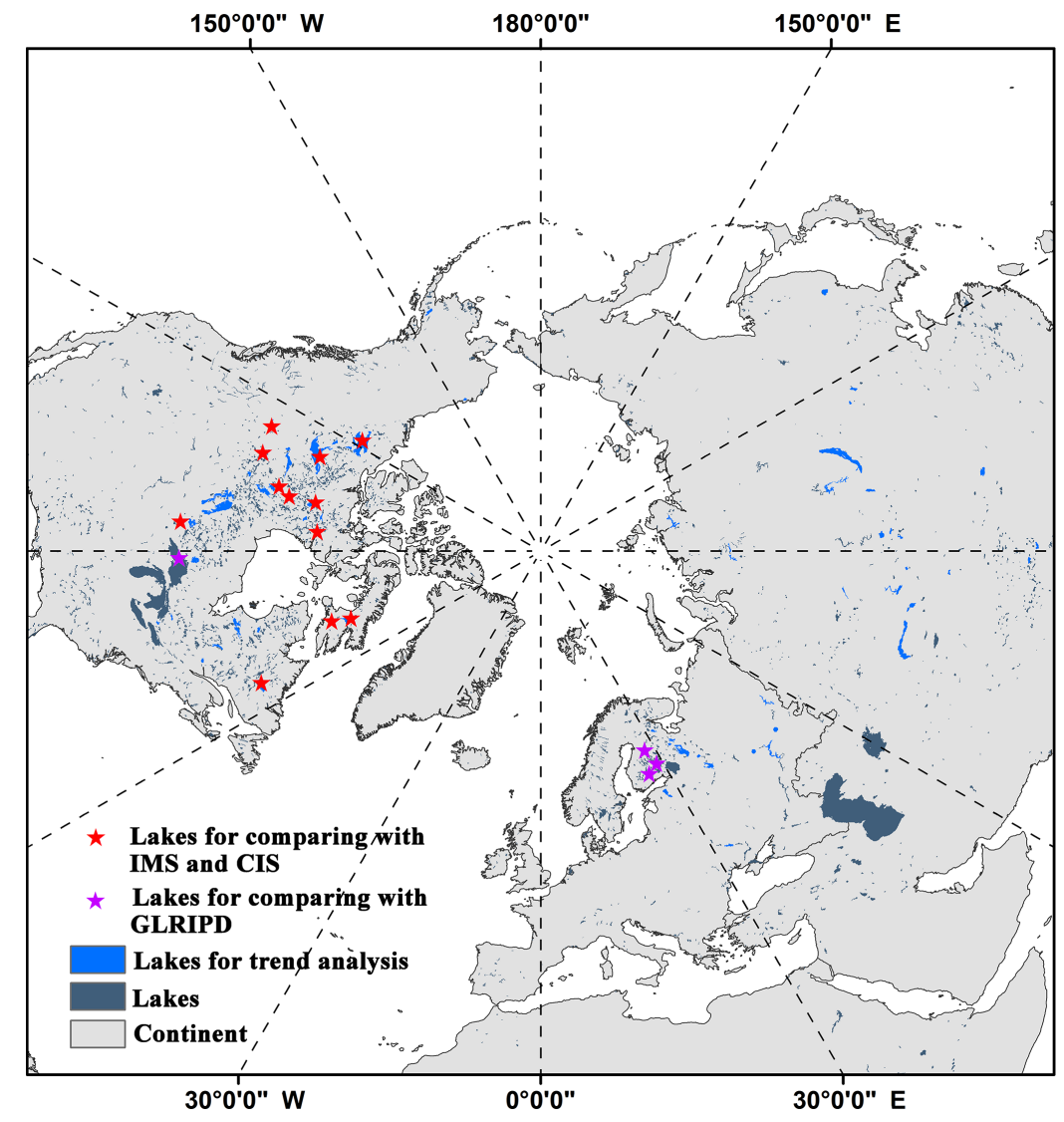

Figure 1. Three sets of lakes selected for the LIP analysis in the Northern Hemisphere mid- and high latitudes $\left(\geq 30^{\circ} \mathrm{N}\right)$. The purple star symbols denote lakes used for evaluating LIP retrievals on a per pixel basis against GLRIPD ground-based observations, including Lake Superior in the USA and Canada and Lake Oulujarvi, Lake Haukivesi, and Lake Paijanne in Finland. The red star symbols denote 12 lakes (Great Bear Lake, Great Slave Lake, Smallwood Lake, Nettiling Lake, Dubawnt Lake, Amadjuak Lake, Wollaston Lake, Baker Lake, Kasba Lake, Lesser Slave Lake, and Peter Pond Lake in Canada and Red Lake in USA) used for the lake-wide comparisons between the LIP results from this study and other regional lake ice phenology records (IMS, CIS). The 71 lakes selected for assessing LIP trends over the 12-year satellite record are in bright blue.

The Level 1 GLWD (Lehner and Döll, 2004) comprises the 3067 largest lakes $\left(\operatorname{area} \geq 50 \mathrm{~km}^{2}\right)$ and 654 largest reservoirs (storage capacity $\geq 0.5 \mathrm{~km}^{3}$ ) worldwide and was used for identifying Northern Hemisphere water bodies and the 71 large lakes used for the LIP assessment (Fig. 1). We also used the MODIS $250 \mathrm{~m}$ land-water mask (MOD44W) for calculating the proportional water coverage of $5 \mathrm{~km}$ resolution pixels within lake areas identified by the GLWD (Carroll et al., 2009).

\subsubsection{Datasets used for algorithm evaluation}

Four lake ice phenology databases were used to evaluate the LIP retrievals, including (a) the GLRIPD (Benson and Magnuson, 2000), (b) the National Oceanic and Atmospheric Administration (NOAA) IMS $4 \mathrm{~km}$ daily snow and ice product (Helfrich et al., 2007; http://www.natice.noaa.gov/ims/), (c) the CIS lake-wide ice product (Howell et al., 2009), and (d) MODIS quick-look images for GBL downloaded from the Geographic Information Network of Alaska (http: //www.gina.alaska.edu).

The GLRIPD contains descriptive ice cover data for 865 lakes and rivers in the Northern Hemisphere (Benson and Magnuson, 2000). The GLRIPD includes groundbased (lakeshore) observations that were used for evaluating the corresponding LIP results for the targeted lakes. The GLRIPD records the first date when the water body was observed to be completely ice covered and the date when the last ice breakup was observed before the summer open water phase for each year of record (Benson and Magnuson, 2000). For evaluating LIP results representing $5 \mathrm{~km}$ lake dominant pixels (water coverage $\geq 90 \%$ ), the lake was assumed completely covered with ice for the period between the first date with complete ice cover and last ice breakup date as recorded in the GLRIPD, while lakes were classified as open water condition for other dates within each annual cycle. Only four lakes were selected for the LIP comparisons due to a predom- 
inance of ice observations from smaller lakes in the GLRIPD database. The temporal coverage of GLRIPD observations for the four lakes that overlaps with the AMSR-E/2 record extends from 2002 to 2007 for Lake Superior and 2003 to 2007 for Lake Oulujarvi, Lake Haukivesi, and Lake Paijanne.

The NOAA IMS daily snow and ice product provides snow and ice cover extent information derived from ground observations and an extensive variety of satellite observations, including AVHRR, GOES (Geostationary Operational Environmental Satellite), SSM/I, and AMSU (Advanced Microwave Sounding Unit) (Helfrich et al., 2007). The CIS lake ice product estimates lake ice cover fraction in tenths (0: open water; 10: complete ice cover) for nearly 140 lakes across Canada and the northern USA from visual interpretation of $1.1 \mathrm{~km}$ resolution NOAA AVHRR and $100 \mathrm{~m}$ resolution RADARSAT ScanSAR imagery (Howell et al., 2009), and MODIS (250-500 m) and Visible/Infrared Imaging Radiometer Suite (VIIRS) I-band $(375 \mathrm{~m})$ observations. The CIS product provides a single lake-wide value per lake on a weekly basis. Both the $4 \mathrm{~km}$ IMS grid products (year 20042015) and CIS data (year 2002-2015) were used for lakewide comparisons against the resulting LIP retrievals.

MODIS quick-look images in true-color composites (bands 1, 4, 3 in RGB) were selected for qualitative visual comparisons with the LIP results. The MODIS images were acquired over the breakup season (2012-2013) with clearsky conditions on 22, 27 June and 8 July 2013 and extensive cloud cover on 5 July 2013. The quick-look products were provided at $250 \mathrm{~m}$ resolution in Albers equal-area conic projection.

In addition, ERA-Interim (Dee et al., 2011) quarter-degree reanalysis surface air temperature (SAT) data was analyzed for evaluating LIP trends over the 71 Northern Hemisphere lakes selected (Fig. 1). ERA-Interim is a global atmospheric model data reanalysis produced by the European Centre for Medium-Range Weather Forecasts, and the data assimilation system used to produce ERA-Interim is based on a 2006 release of the IFS (Cy31r2) including a four-dimensional variational analysis (4D-Var) with a $12 \mathrm{~h}$ analysis window (Dee et al., 2011). Daily average SAT over the spring (MAM) and fall (SON) seasons of years 2002 to 2015 was extracted for the quarter-degree grids encompassing the lake centers.

\subsubsection{Data processing}

To derive the LIP estimates, AMSR-E/2 $36.5 \mathrm{GHz}$ orbital swath $T_{\mathrm{b}}$ data were spatially resampled to a $5 \mathrm{~km}$ resolution polar EASE-Grid (version 2) format using an inverse distance squared weighting method (Ashcroft and Wentz, 2000; Brodzik et al., 2012, 2014). It is worth noting that the $T_{\mathrm{b}}$ spatial gridding is posted at $5 \mathrm{~km}$ resolution while the original 36.5 GHz AMSR-E/2 observations have coarser native sensor footprints ( $\sim 12 \mathrm{~km}$ for AMSR-E and $9 \mathrm{~km}$ for AMSR2). The finer grid spacing is intended to facilitate product comparisons and analyses with other alternative lake products de- rived at similar resolutions, including the NOAA IMS $4 \mathrm{~km}$ daily snow and ice product and a land surface fractional open water cover dataset derived from AMSR-E/2 at $5 \mathrm{~km}$ resolution (Du et al., 2016). Before carrying out the $T_{\mathrm{b}}$ gridding process, an additional altitude correction was made to the AMSR-E data by considering the actual surface of the Earth instead of that of an ideal Earth ellipsoid. The same altitude correction was used for the AMSR2 L1R data (Maeda et al., 2016). According to Maeda et al. (2016), an altitude of $3000 \mathrm{~m}$ leads to about $4 \mathrm{~km}$ displacement of AMSR2 $T_{\mathrm{b}}$ geolocation. Thus the altitude correction is a necessary prerequisite to ensure reliable analysis of AMSR-E/2 lake ice phenology retrievals at higher elevations, including the QinghaiTibetan Plateau.

The finer-resolution MOD44W static open water maps were aggregated to the same $5 \mathrm{~km}$ resolution polar EASEgrid 2.0 projection format as LIP and used with the GLWD to identify dominant lake pixels (water coverage $\geq 90 \%$ ) where the AMSR-E/2 lake ice detection was made. The $250 \mathrm{~m}$ resolution MODIS quick-look images were re-projected to the EASE-grid 2.0 projection for visual comparisons with the LIP results.

\subsection{Algorithm theoretical basis}

Accurate modeling of satellite observed microwave emissions from lakes is complex and requires good understanding of microwave scattering and emitting mechanisms from atmosphere and lake elements. Microwave emissions from a non-scattering atmosphere are governed by both air temperature and atmosphere optical thickness, which is approximately the sum of the optical thickness of oxygen, cloud liquid water, and atmospheric water vapor (Wang and Tedesco, 2007; Du et al., 2015). Microwave emissions from a lake with an upper layer that may consist of water, ice, and snow are determined by a number of factors; these factors include lake surface roughness, water dielectric properties mainly affected by water salinity and temperature, ice thickness and dielectric properties, and snow cover dielectric properties mainly controlled by snow density and wetness, snow particle size, and stratification of snow and ice layers (Du et al., 2010; Lemmetyinen et al., 2010, 2011). Despite the complexity of the lake emission problem, sharp changes in satellite microwave $T_{\mathrm{b}}$ observations at multiple frequencies are evident during the transitions between lake freeze-up and breakup periods. For example, previous studies showed low $T_{\mathrm{b}}$ measurements $(<150 \mathrm{~K})$ from $\mathrm{H}$-polarized $37 \mathrm{GHz}$ SMMR data over low-emissivity open water regions of the Great Lakes and Gulf of Mexico, contrasting with much higher $T_{\mathrm{b}}$ values ( $>215 \mathrm{~K}$ ) over western Lake Superior under frozen conditions due to the high emissivity of lake ice (Ferraro et al., 1986). Similarly, the H-polarized emissivity at $35 \mathrm{GHz}$ and $50^{\circ}$ incidence angle is approximately 0.356 for a calm and unfrozen lake at $0-8{ }^{\circ} \mathrm{C}$ and is well below the emissivity ( $>0.610$ ) of different types of snow and ice (Mätzler, 
1994). These studies suggest a very large Ka-band $T_{\mathrm{b}}$ difference $(>60 \mathrm{~K})$ between a lake at $0^{\circ}$ with no ice and $100 \%$ ice coverage. The timing of ice formation and disappearance can therefore be determined by the large characteristic $T_{\mathrm{b}}$ changes indicated from satellite passive microwave observations (Walker and Davey, 1993; Che et al., 2009; Kang et al., 2012).

\subsection{Algorithm development}

For identifying freeze-up and breakup events, a moving $t$ test method (MTT) was introduced to detect abrupt temporal changes in the H-polarized $36.5 \mathrm{GHz} T_{\mathrm{b}}$ observations from AMSR-E and AMSR2. Selection of $36.5 \mathrm{GHz} T_{\mathrm{b}}$ observations from other available AMSR-E/2 frequencies represents a compromise between finer spatial resolutions gained from higher frequencies and less sensitivity to potential atmosphere contamination available from lower $T_{\mathrm{b}}$ frequency observations. Moreover, H-polarization $T_{\mathrm{b}}$ retrievals were used instead of $\mathrm{V}$-polarization data due to their reported higher sensitivity to lake freeze-up/breakup signals (Kang et al., 2012). The detailed lake ice detection method used in this study is described below.

\subsubsection{Step 1: detection of abrupt changing point}

The MTT method was initially developed for detecting abrupt climate changes by examining whether the difference between the mean values of two subsamples is statistically significant (Jiang and You, 1996; Xiao and Li, 2007). As detailed in the literature (Xiao and Li, 2007), for a time series with $n$ elements, a $t$ test is made at each point $x_{k}$ for evaluating the difference of the two subsets $x_{k 1}$ and $x_{k 2}$ ( $n_{1} \leq k \leq n-n_{2} ; n_{1}, n_{2}$ are the subsample sizes) before and after $x_{k}$. The $t$ statistic is defined as

$$
t=\frac{\overline{x_{k 2}}-\overline{x_{k 1}}}{s_{k} \sqrt{\frac{1}{n_{1}}+\frac{1}{n_{2}}}},
$$

where $s_{k}=\sqrt{\frac{n_{1} s_{k 1}^{2}+n_{2} s_{k 2}^{2}}{n_{1}+n_{2}-2}}, \overline{x_{k 2}}$ and $\overline{x_{k 1}}$ are the mean values, and $s_{k 1}^{2}$ and $s_{k 2}^{2}$ are the variances for the two subsets, respectively. Given a significance level $\alpha, x_{k}$ is determined as an abrupt changing point if $|t| \geq t_{\alpha}$. In this study, we define $\alpha$ as 0.005 and temporal subsample sizes as $n_{1}=n_{2}=20$ days. The 20-day requirement is set for excluding potentially dynamic $T_{\mathrm{b}}$ changes caused by short-term weather events such as storms.

\subsubsection{Step 2: determining reference $T_{\mathrm{b}}$ values for lake ice conditions}

For a group of detected changing points sequenced from $p$ to $q$, the mean $T_{\mathrm{b}}$ values $\overline{x_{p 1}}$ and $\overline{x_{q 2}}$ as defined in Eq. (1) are representative of the satellite observations over the stable stages before and after the changing period, respectively.
For a lake experiencing a complete annual freeze-up/breakup cycle, at least two groups of seasonal changing points can be defined. Besides the sharp $T_{\mathrm{b}}$ increases as lake water freezes, the melting of dry snow overlying lake ice to wet snow can induce further increases in the observed $T_{\mathrm{b}}$ since microwave emissions from wet snow are close to that of a blackbody (Ulaby et al., 1986). Therefore, assuming $\overline{x_{p 1}}$ is always smaller than $\overline{x_{q 2}}$, we define the lowest $\overline{x_{p 1}}$ of all changing groups as the reference $T_{\mathrm{b}}$ for lake water and $\overline{x_{q 2}}$ from the same group as the reference $T_{\mathrm{b}}$ for lake ice. Lake ice conditions for a given date $i$ can thus be determined as

Ice dominant if $T_{\mathrm{b}_{i}} \geq T_{\mathrm{b}_{\text {threshold }}}$

Water dominant if $T_{\mathrm{b}_{i}}<T_{\mathrm{b}_{\text {threshold }}}$,

where $T_{\mathrm{b}_{i}}$ is the $T_{\mathrm{b}}$ for date $i, T_{\mathrm{b}_{\text {threshold }}}=\left(\overline{x_{p 1}}+\overline{x_{q 2}}\right) / 2.0$, and $\left|\overline{x_{p 1}}-\overline{x_{q 2}}\right|$ is required to be larger than $30 \mathrm{~K}$ since liquidice phase changes of lake water can lead to large $T_{\mathrm{b}}$ changes exceeding $60 \mathrm{~K}$ as introduced in Sect. 2.2.

\subsubsection{Step 3: deriving lake ice status}

Based on Eq. (2), lake ice status is first derived for each point $i$ in the $T_{\mathrm{b}}$ time series where $n_{1} \leq i \leq n-n_{2}$ using a temporally smoothed $T_{\mathrm{b}_{i}}$ defined as the mean $T_{\mathrm{b}}$ within the range $\left[i-n_{1} / 2, i+n_{2} / 2\right]$. The use of a smoothed $T_{\mathrm{b}_{i}}$ minimizes the impact of high temporal frequency events in the time series while emphasizing lower frequency lake icecovered and ice-free signals. Thus for point $j$, whose temporally adjacent points have different lake ice status, the refined lake ice detection is carried out using Eq. (2) for each observed $T_{\mathrm{b}}$ value within the range $\left[j-n_{1} / 2, j+n_{2} / 2\right]$. For running the algorithm, missing daily $T_{\mathrm{b}}$ retrievals were obtained through temporal linear interpolation of adjacent successful $T_{\mathrm{b}}$ retrievals acquired from the same ascending orbits (Kim et al., 2012). However, only the lake ice detection results corresponding to the actual satellite observations were output for further analysis. The above lake ice detection process was carried out for each $T_{\mathrm{b}}$ time series from AMSR-E and AMSR2 separately because of the 7-month gap (4 October 2011-18 May 2012) in the observation records between the two sensors.

The above MTT algorithm was applied to all $5 \mathrm{~km}$ pixels with dominant $(\geq 90 \%)$ open water coverage within the Northern Hemisphere domain on a daily basis to generate the AMSR-E/2 LIP dataset describing lake ice conditions. The dominant $(\geq 90 \%)$ open water coverage criterion is set to include lake pixels while reducing potential contamination from adjacent land areas.

\subsection{Evaluation of lake ice phenology retrievals}

The resulting LIP retrievals were evaluated against other available lake ice databases, including the GLRIPD, IMS, and CIS products. The remotely sensed lake ice phenology variable definitions from this study are summarized in Ta- 
Table 1. Definitions of remotely sensed lake ice phenology variables from this study in relation to the other lake ice observational datasets used for the LIP validation assessment on a per pixel basis and for entire lakes.

\begin{tabular}{ll|ll}
\hline & Per pixel basis & \multicolumn{1}{c}{ Entire lake } \\
\hline Terminology & Definition & Terminology & Definition \\
\hline Ice-on date & $\begin{array}{l}\text { Day of year on which a pixel be- } \\
\text { comes totally ice covered }\end{array}$ & $\begin{array}{l}\text { Complete freeze over } \\
\text { (CFO) date }\end{array}$ & $\begin{array}{l}\text { Day of year when all pixels become } \\
\text { totally ice covered }\end{array}$ \\
\hline Ice-off date & $\begin{array}{l}\text { Day of year on which a pixel be- } \\
\text { comes totally ice free }\end{array}$ & $\begin{array}{l}\text { Water clear of ice } \\
\text { (WCI) date } \\
\text { Ice cover duration of } \\
\text { entire lake (ICDe) }\end{array}$ & $\begin{array}{l}\text { Day of year when all pixels become } \\
\text { totally ice free } \\
\text { number of days between CFO and } \\
\text { WCI }\end{array}$ \\
\hline & \multicolumn{2}{|c}{ Associated datasets: LIP, IMS, CIS } \\
\hline
\end{tabular}

ble 1 relative to the other lake ice observational data records used for LIP validation on a per pixel basis and for entire lakes (Kang et al., 2012; Duguay et al., 2015a).

For comparing with the GLRIPD ground-based records, the LIP ice-on and ice-off dates were extracted for the $5 \mathrm{~km}$ pixel closest to the GLRIPD observation site. The pixel representing Lake Superior has $100 \%$ water coverage (lat/long: $46.78^{\circ} \mathrm{N} /-90.45^{\circ} \mathrm{W}$ ). For the pixels representing Lake Oulujarvi (lat/long: $64.3^{\circ} \mathrm{N} / 27.3^{\circ} \mathrm{E}$ ), Lake Haukivesi (lat/long: $62.07^{\circ} \mathrm{N} / 28.57^{\circ} \mathrm{E}$ ), and Lake Paijanne (lat/long: $61.19^{\circ} \mathrm{N} / 25.55^{\circ} \mathrm{E}$ ), the water coverage is $100,91.4$, and $95.7 \%$, respectively.

The LIP-derived annual CFO (complete freeze over) and WCI (water clear of ice) dates for the 12 selected lakes were also compared with alternative IMS and CIS ice products. Different from the dominant open water coverage ( $\geq 90 \%)$ requirement set for generating the LIP database, only lake pixels with complete $(100 \%)$ open water coverage and outside of the $5 \mathrm{~km}$ land buffer zone were considered in the IMS and LIP comparisons; this same criterion was set for the lake-wide comparisons to minimize potential contamination from adjacent land areas since the native $36.5 \mathrm{GHz}$ AMSR-E/2 footprint ranges from approximately 9 to $12 \mathrm{~km}$. Considering possible retrieval uncertainties, the CFO-WCI dates derived from the LIP and IMS datasets were slightly adjusted from the definitions in Table 1 and were determined as the dates when most ( $99.5 \%$ for this study) lake pixels were identified as ice/water. The CIS CFO dates were determined when the reported lake ice fraction was 9 , followed by changes from 9 to 10 , and WCI dates were derived when the reported lake ice fraction was 1 followed by changes from 1 to 0 . The derived CIS CFO-WCI dates are comparable with corresponding LIP results, excluding waters adjacent to land such as part of the eastern arm of the GSL where a high concentration of islands exists and ice formation/melting timing was found to be different from other GSL areas (Howell et al., 2009; Kang et al., 2012).

\subsection{Analysis of lake ice phenology changes}

Based on the LIP database covering the AMSR-E (June 2002-October 2011) and AMSR2 (June 2012December 2015) observation periods, we selected 71 lakes in the Northern Hemisphere from 250 of the world's largest lakes (including both natural and artificial lakes), as described in the GLWD, to analyze potential lake ice phenology trends, including WCI date, CFO date, and annual ICDe. In order to assess the pattern of recent Northern Hemisphere lake ice phenology changes, a temporal trend analysis was performed on the 12-year LIP record for each of the 71 lakes. The assumption of independent observations was first determined using a correlogram (Noguchi et al., 2011). For ice phenology time series without significant autocorrelation detected, the magnitude and significance of temporal trends were tested using the non-parametric Mann-Kendall and Sen's methods (Sen, 1968; Duguay et al., 2006). Alternatively, for a time series with persistent serial correlation, additional prewhitening approaches were applied (Zhang et al., 2000). For evaluating LIP-derived lake phenology, a similar temporal trend analysis was also carried out on the ERAInterim daily average SAT over the lakes for the spring and fall seasons from 2002 to 2015 .

\section{Results}

\subsection{LIP comparisons with GLRIPD lake observations}

The lake ice status derived from the LIP and GLRIPD records are plotted for the selected large lake validation sites (Fig. 2), including Lake Superior (a), Lake Oulujarvi (b), Lake Haukivesi (c), and Lake Paijanne (d), along with the daily ascending AMSR-E/2 $T_{\mathrm{b}}$ retrievals. The LIP results show generally strong agreement with the GLRIPD site observations of lake ice conditions for the four lakes examined, with overall retrieval accuracy of $95.4 \%$. The lake ice/water retrieval error at the beginning of the record for Lake Haukivesi (Fig. 2c) may be caused by partial melting 

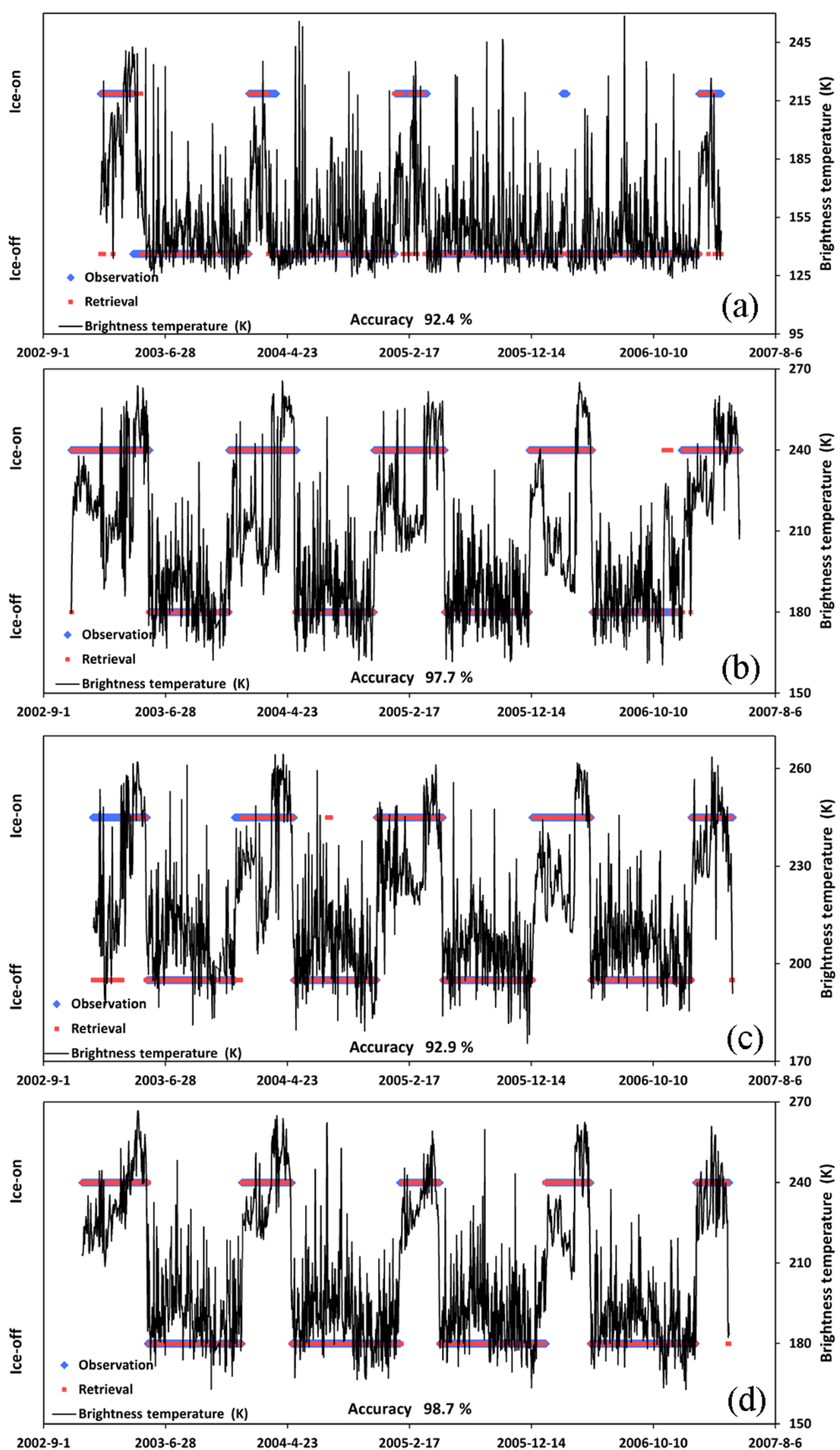

Figure 2. Comparison of lake ice status for Lake Superior, USA and Canada (a), Lake Oulujarvi, Finland (b), Lake Haukivesi, Finland (c), and Lake Paijanne, Finland (d), derived from the Global Lake and River Ice Phenology Database (GLRIPD) (blue dots) and AMSR Lake Ice Phenology retrievals (LIP) (red dots). The AMSR-E/2 $36.5 \mathrm{GHz}$ H-polarized daily $T_{\mathrm{b}}$ retrievals used in the LIP algorithm are also plotted for reference (black line). The blue/red dots represent GLRIPD/LIP-derived ice conditions as indicated by their $y$ axis positions for the dates described by their $x$ axis coordinates. 
Table 2. Summary of the comparison results for water clear of ice (WCI) and complete freeze over (CFO) dates derived from AMSR Lake Ice Phenology (LIP), Canadian Ice Service (CIS) datasets for the period 2002-2015, and the NOAA/IMS (IMS) dataset for the period 20042015. $R_{\text {LIP,CIS/IMS }}$ denotes the correlation coefficient between the LIP and CIS/IMS datasets; $D_{\text {LIP,CIS/IMS }}$ is the average difference (unit: day) in WCI or CFO dates calculated by LIP minus CIS/IMS.

\begin{tabular}{lrrrr|rrrr}
\hline & \multicolumn{3}{c}{ Statistics of WCI date comparisons } & \multicolumn{3}{c}{ Statistics of CFO date comparisons } \\
\cline { 2 - 9 } Lake name & $R_{\text {LIP,CIS }}$ & $R_{\text {LIP,IMS }}$ & $D_{\text {LIP,CIS }}$ & $D_{\text {LIP,IMS }}$ & $R_{\text {LIP,CIS }}$ & $R_{\text {LIP,IMS }}$ & $D_{\text {LIP,CIS }}$ & $D_{\text {LIP,IMS }}$ \\
\hline Great Bear & 0.90 & 0.94 & -2 & -3 & 0.90 & 0.54 & 0 & 3 \\
Great Slave & 0.85 & 0.91 & -6 & -5 & 0.72 & 0.63 & -2 & 3 \\
Smallwood & 0.66 & 0.62 & -6 & -4 & 0.70 & -0.08 & -4 & 1 \\
Nettiling & 0.91 & 0.84 & -9 & -4 & 0.92 & 0.33 & -2 & 10 \\
Dubawnt & 0.92 & 0.79 & -8 & 1 & 0.34 & 0.78 & -9 & -5 \\
Amadjuak & 0.89 & 0.80 & -7 & -4 & 0.87 & 0.27 & -2 & 6 \\
Wollaston & 0.95 & 0.87 & -5 & 0 & 0.66 & -0.42 & -7 & 9 \\
Baker & 0.80 & 0.70 & -10 & -1 & 0.60 & 0.26 & -7 & 0 \\
Kasba & 0.96 & 0.77 & -5 & 3 & 0.19 & 0.61 & -7 & 1 \\
Lesser Slave & 0.82 & 0.92 & -12 & -5 & 0.72 & 0.75 & -11 & -3 \\
Red Lake & 0.86 & 0.91 & -4 & 2 & 0.77 & 0.72 & -10 & -9 \\
Peter Pond & 0.85 & 0.95 & -7 & -1 & 0.88 & 0.54 & -5 & 0 \\
\hline Average & 0.86 & 0.84 & -7 & -2 & 0.69 & 0.41 & -6 & 1 \\
\hline
\end{tabular}

of lake ice in January and February 2003 that resulted in low AMSR-E/ $2 T_{\mathrm{b}}$ observations. While the AMSR-E/2 $T_{\mathrm{b}}$ observations show dynamic daily fluctuations due to changing water and atmosphere properties (Sect. 2.2), lake freeze-up and breakup events constitute the dominant factors affecting seasonal $T_{\mathrm{b}}$ changes. The effects of higher temporal frequency $T_{\mathrm{b}}$ variations are minimized in the LIP algorithm by the predefined 20-day subsample sizes (Sect. 2.3), which represent a compromise between the algorithm's capability in capturing shorter-term lake ice formation or melt events, and potentially degraded lake ice/water seasonal retrieval accuracy.

\subsection{LIP comparisons against MODIS imagery, IMS and CIS products}

An example visual comparison between the LIP results and MODIS quick-look imagery (Fig. 3) shows the 2013 spring ice breakup process over the GBL. In this example, both datasets show a general onset of lake ice breakup on 22 June (Fig. 3a), similar spatial ice distribution patterns on 27 June (Fig. 3b), and ice-free conditions on 8 July (Fig. 3d). Despite extensive cloud presence in the MODIS image for 5 July, both MODIS and LIP show remaining ice cover on the western edge of GBL (Fig. 3c). A few remaining pixels along the GBL coast line were identified as ice covered in the LIP results for 8 July (Fig. 3d); the apparent LIP retrieval error is attributed to land contamination, while the affected pixels are within the $5 \mathrm{~km}$ land buffer zone (Sect. 2.4) and excluded in the final LIP product.

The LIP products were compared against similar lake ice phenology metrics from the IMS and CIS datasets for the 12 North American study lakes. For GBL and GSL, the LIP products agreed well with the CIS records; temporal corre- lations ( $R$ value) of 0.90 and 0.85 were observed for the WCI dates for GBL (Fig. 4a) and GSL (Fig. 4b), respectively, while correlations of 0.90 and 0.72 were determined for GBL (Fig. 4c) and GSL (Fig. 4d) CFO dates. The LIP results were also strongly correlated with the IMS record on derived WCI dates for both lakes $(R=0.94$ for GBL and $R=0.91$ for GSL) (Fig. 4a, b). However, lower correspondence was found between LIP and IMS CFO dates, with respective correlations of 0.54 and 0.63 for GBL and GSL (Fig. 4c, d). These results indicate that the LIP-derived lake ice phenology variables are generally consistent with the IMS and CIS records for the two lakes examined, with generally higher (lower) correspondence for WCI (CFO) dates. For GBL, the LIP estimated CFO dates occur similar to the CIS records (0-day difference) and later than the IMS records by about 3 days; the LIP WCI dates occur earlier than the CIS and IMS records by about 2 and 3 days, respectively. For GSL, the LIP record also shows earlier (later) CFO than the CIS (IMS) records by about 2 (3) days and earlier WCI dates than both CIS and IMS by about 6 and 5 days, respectively. The intercomparisons between CIS and IMS show average 5- and 0-day differences in respective $\mathrm{CFO}$ and WCI dates for their overlapping period from 2004 to 2015 for GBL; corresponding differences for GSL are 5 and 1 day, respectively. The differences between the LIP and CIS/IMS metrics are of similar magnitude as the differences between the CIS and IMS metrics.

The LIP comparison results for all 12 study lakes are summarized in Table 2. Similar to the comparisons for GBL and GSL, the LIP results are strongly correlated with both CIS and IMS records for WCI dates, with respective average temporal correlations ( $R$ value) of 0.86 and 0.84 . For CFO 

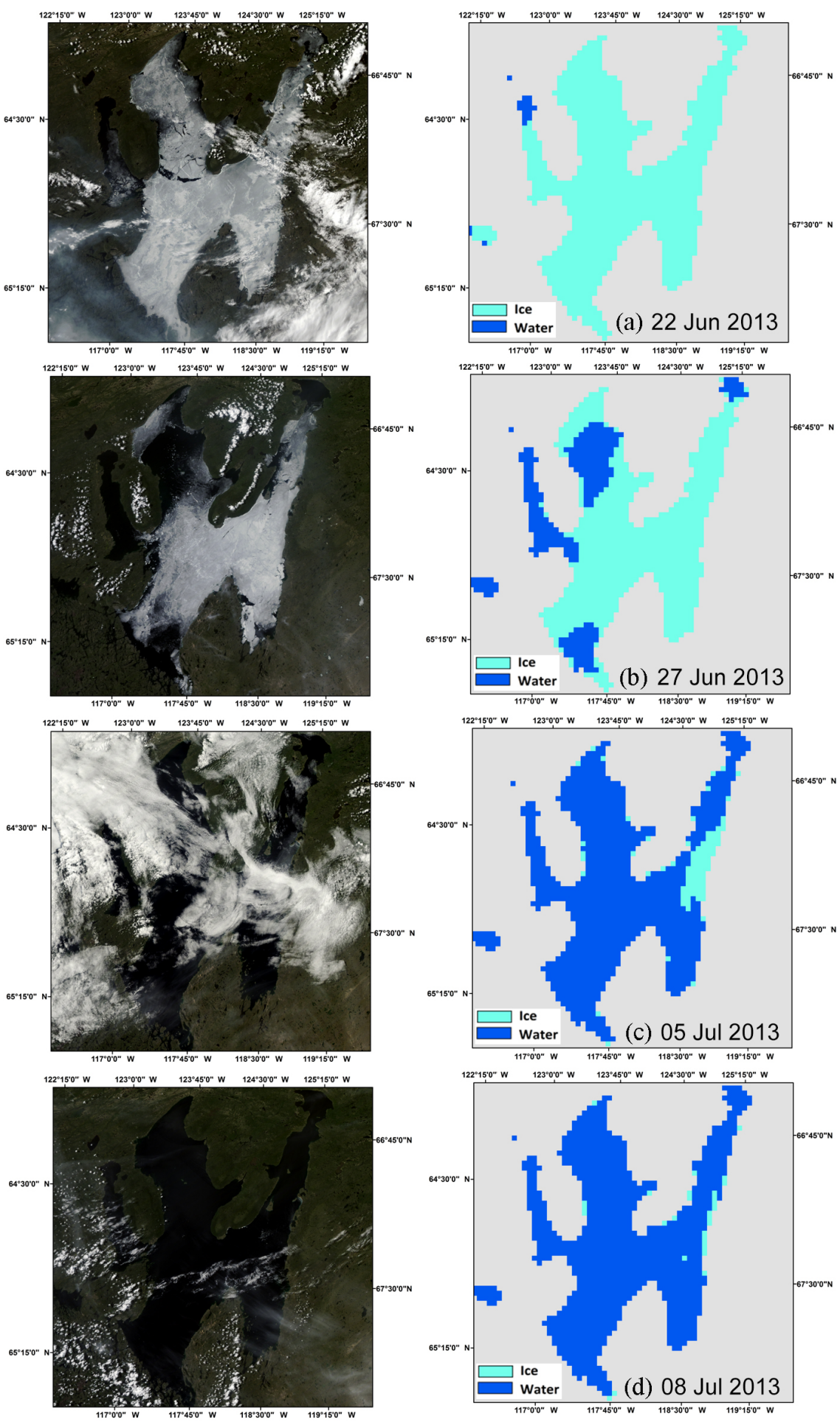

Figure 3. Comparisons between MODIS quick-look images (left column) and AMSR-E/2 LIP results (right column) for Great Bear Lake (GBL) on 22 June (a), 27 June (b), 5 July (c), and 8 July 2013 (d). The images are in the EASE-GRID version 2 polar projection format, consistent with the underlying AMSR-E/2 gridded $T_{\mathrm{b}}$ dataset used for the LIP classification. 

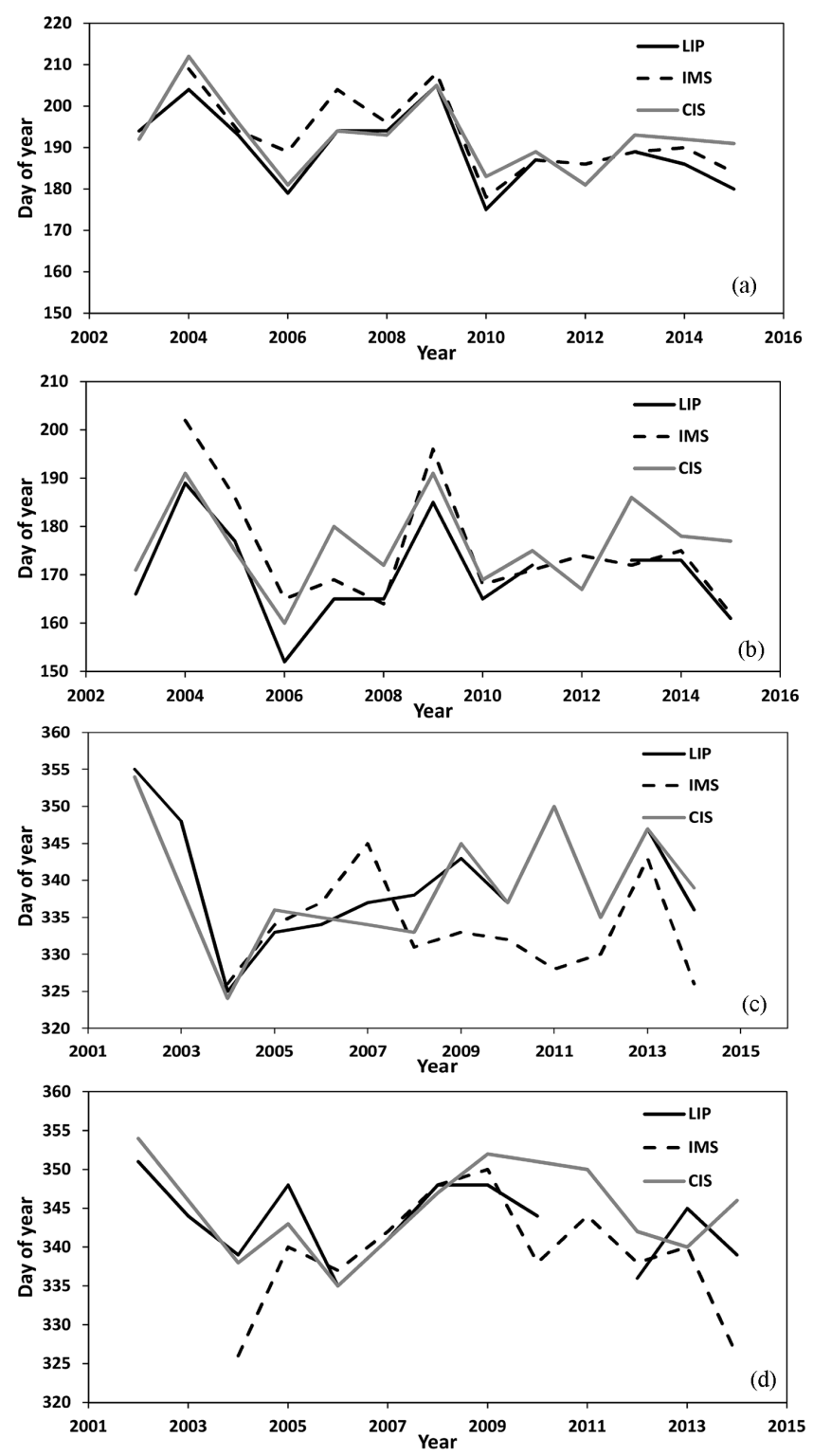

Figure 4. Comparisons of water clear of ice (WCI) dates for (a) Great Bear Lake and (b) Great Slave Lake and complete freeze over (CFO) dates for (c) Great Bear Lake and (d) Great Slave Lake, derived from the AMSR-E/2 Lake Ice Phenology (LIP) dataset developed in this study. The LIP results are compared against similar metrics derived from the NOAA/IMS (IMS) and Canadian Ice Service (CIS). Missing LIP data from 2011 to 2012 denote the period between the end of AMSR-E operations and the start of the AMSR2 record.

dates, the average correlation between LIP and CIS results are also strong $(R=0.69)$ while only moderate correlation $(R=0.41)$ was found between the LIP and IMS results. The LIP estimated CFO dates tend to occur earlier than the CIS record by about 6 days and later than the IMS record by about 1 day. The LIP record also shows earlier WCI dates than the CIS and IMS records by about 7 and 2 days, respectively.

\subsection{Analysis of LIP lake ice phenology changes}

The magnitude and direction of LIP trends were calculated for the 71 Northern Hemisphere study lakes for the 12-year AMSR-E/2 record. Among all 71 lakes, 43 (60.6\%) show declining trends in ICDe, indicating an increasingly shorter ice cover season, while the other lakes show either increasing or minimal change in annual ice cover (Fig. 5). However, no observed ice trends are statistically significant $(p \geq 0.05)$. The lack of significant trends is attributed to large yearly variability ( \pm 13.3 day) in average ICDe and a relatively short (12-year) LIP observation record. The changing trends also demonstrate a latitudinal pattern, as $81.0 \%$ of the lakes (17 out of 21) at higher latitudes $\left(>60^{\circ} \mathrm{N}\right)$ show declining ICDe trends while only $45.0 \%$ (9 out of 20) of lower-latitude $\left(<50^{\circ} \mathrm{N}\right)$ lakes show a similar trend.

The observed changes in ICDe are the net result of changes in fall CFO and spring WCI dates. A tendency toward earlier WCI dates was found for 40 lakes, including 5 lakes (Lake Vygozero, Lake Barun-Torey, Lake Segozero, Novosibirsk Reservoir in Russia and Lake Teshekpuk in USA) with significant LIP trends. However, no lakes showed significant trends toward later spring breakup. Similar to the ICDe analysis, most high-latitude lakes $(81.0 \%$ of lakes above $60^{\circ} \mathrm{N}$ ) show earlier spring thaw trends, while only $45.0 \%$ of lower-latitude $\left(<50^{\circ} \mathrm{N}\right)$ lakes show similar trends. A tendency toward delayed CFO was found for 35 of the 71 lakes $(49.3 \%)$ examined, but no trends are statistically significant $(p \geq 0.05)$. Lake Bosten in China was the only lake with a significant trend toward earlier freeze-up. There was no clear relationship between changes in lake $\mathrm{CFO}$ dates with latitude.

Similar analysis of quarter-degree ERA-Interim SAT over the study lakes indicates a much stronger warming trend in spring $\left(0.073^{\circ} \mathrm{C}_{\text {year }}{ }^{-1}\right)$ than fall $\left(0.023^{\circ} \mathrm{C}_{\text {year }}{ }^{-1}\right)$. Moreover, similar to the latitudinal pattern shown in the LIP-based analysis, the SAT increase in the spring is positively correlated with latitude $(R=0.33 ; p=0.005)$ indicating greater warming during the study period at higher latitudes, while no SAT correlation with latitude is found for the fall $(R \sim 0.0)$.

\section{Discussion}

We developed a new satellite approach for regionally consistent classification of ice phenology for large lakes in the Northern Hemisphere from the AMSR-E/2 sensor record. We used similar $36.5 \mathrm{GHz} \mathrm{H}$-polarization daily brightness temperature retrievals from AMSR-E and AMSR2 sensor records with $5 \mathrm{~km}$ posted spatial resolution. The resulting LIP record documents the timing and duration of seasonal lake phenology events of $5 \mathrm{~km}$ lake pixels (water coverage $\geq 90 \%$ ) over the 12-year AMSR-E/2 record. The LIP results showed strong agreement with GLRIPD site observations from four lakes, with agreement ranging from 92.4 to 

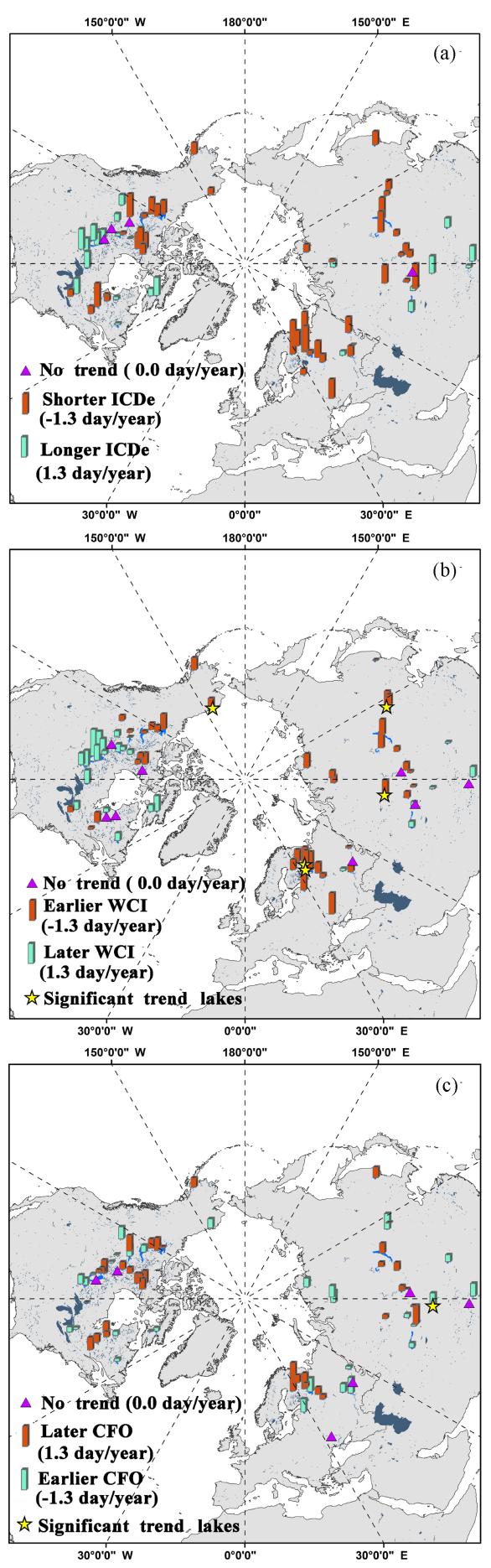

Figure 5. Changing trends of (a) ice cover duration (ICDe), (b) water clear of ice (WCI) dates, and (c) complete freeze over (CFO) dates of 71 lakes for the period 2002-2015. Lake changing trends are shown by bar symbols whose heights are proportional to the trend magnitudes; the significant trend lakes are marked by yellow stars, while purple triangles denote lakes where no trend was detected (rate of change is $\sim 0.0$ day year ${ }^{-1}$ ).
98.7\%. Differences between the LIP and GLRIPD results can be attributed to several factors. First, each database has a different definition of lake ice conditions; lake ice coverage determined by satellite microwave sensors is dependent on ice thickness, which may vary from the ice detection approach used by on-site observers or observed from optical sensors. According to the literature (Hall et al., 1981), lake ice thickness and $T_{\mathrm{b}}$ are linearly related for multiple frequencies (from 5 to $37 \mathrm{GHz}$ ). The reported maximum microwave penetration depths of fresh lake ice at $37 \mathrm{GHz}$ range from 0.70 to $1.4 \mathrm{~m}$, depending on ice temperatures (Chang et al., 1997; Surdyk, 2002; Kang et al., 2014). This implies that the formation of thin ice, resulting in relatively small $T_{\mathrm{b}}$ increases, may not be detectable using the defined $T_{\mathrm{b}}$ thresholds in the LIP algorithm. Differences between the LIP and GLRIPD results may also reflect spatial inconsistencies in lake observation area between the ground-based lakeshore observations and the coarser satellite footprint. Thus, the lake area observed on-site may not completely overlap with the AMSR-E/2 lake pixel used for the LIP classification. The GLRIPD also does not provide explicit descriptions of lake ice status for the period between the first date when the water body was completely ice covered and the date when the last ice breakup occurred; thus, short-term events such as temporary ice melting or formation may not be recorded in the GLRIPD. For example, though identified as ice covered in the GLRIPD, Lake Oulujarvi was more likely to have thawed on 9 January 2007 since the low $T_{\mathrm{b}}(178.7 \mathrm{~K})$ observation is more characteristic of open water emissions (Fig. 2b). The satellite $T_{\mathrm{b}}$ observations at $36.5 \mathrm{GHz}$ are also affected by other factors than surface freeze-up/breakup transitions, including changes in atmosphere water vapor and cloud liquid water (e.g., Sect. 2.2). For example, the LIP detected iceon conditions for Lake Haukivesi Finland in mid-summer (30 July 2004) (Fig. 2c), which is likely incorrect and may be due to increased atmosphere water vapor concentrations under warm summer conditions, resulting in a large $T_{\mathrm{b}}$ increase similar to a seasonal freeze-up event.

In the lake-based comparisons for the 12 lakes examined, including GSL and GBL, the LIP results show strong correspondence with the CIS product for both CFO and WCI dates and similar high correlations with the IMS results for WCI dates; however, the LIP WCI (CFO) dates differ by approximately 7 (6) days from the CIS and 2 (1) days from the IMS. These differences are attributed to the different sensor spatial/temporal resolutions and retrieval methods associated with the different products. As described in Sect. 2.1.3, the CIS product is derived for individual lakes from visual interpretation of imagery from optical and SAR sensors and has a \pm 1 -week accuracy due to the weekly product reporting. Both CIS and IMS products rely partially on observations from optical sensors such as AVHRR and their accuracy is influenced by adverse weather conditions, including the presence of cloud cover. IMS-derived lake ice products have been widely used in monitoring global climate change (Duguay et 
al., 2013, 2014, 2015b); however, the IMS detected freeze onset was found to be too early for some lakes in northern Québec, presumably due to misclassification by inclusion of coarse-resolution satellite passive microwave observations during periods of prolonged cloud cover (Brown and Duguay, 2012; Brown et al., 2014); this may cause the low correlations between LIP and IMS CFO dates, as well as a delayed LIP CFO bias relative to IMS.

In addition, the relatively coarse spatial resolution of AMSR-E/2 observations limits capabilities for resolving lake ice conditions of finer-scale water bodies. Spaceborne and airborne optical-TIR and radar sensors are capable of improved delineation of smaller lakes and rivers (Chu et al., 2016), but at the expense of degraded temporal fidelity for regional and global applications.

As a proxy indicator of climate variability and change (Duguay et al., 2006), lake ice phenology variables and their changing trends are important for monitoring and understanding climate change and its feedbacks. As described above, only 5 of the 71 lakes examined showed statistically significant trends towards earlier WCI dates while no lake showed a significant later CFO trend. Earlier ice breakup events are signs of warmer spring conditions, which promote melting and breakup of lake ice and a lower surface albedo that absorbs more incoming solar radiation and further intensifies the rate of ice melt (Mishra et al., 2011). These results are also consistent with previous studies over Canada that found a general trend toward earlier springs and WCI dates particularly over western Canada but little change in isotherm and CFO dates in fall (Duguay et al., 2006). Our results also indicate that lakes at higher latitudes are more likely to experience trends toward earlier spring ice breakup and shorter ICDe, which is consistent with enhanced warming trends at higher latitudes (Solomon et al., 2007; Deutsch et al., 2008). The above ice phenology trends coincide with regional SAT trends from ERA-Interim that show an average spring warming rate that is more than triple that of fall, as well as stronger warming trends for higher latitudes.

Though the LIP lake ice phenology trends are generally consistent with regional climate warming (Magnuson et al., 2000; Solomon et al., 2007), further analysis based on a longer period of record is needed for distinguishing longterm climate trends from large interannual variability and periodic climate cycles, including the North Atlantic Oscillation (NAO), El-Niño Southern Oscillation (ENSO), and Pacific Decadal Oscillation (PDO) (Mishra et al., 2011).

\section{Conclusions}

Lake ice phenology is strongly influenced by variations in air temperature, while consistent long-term records of lake ice changes provide a sensitive climate change indicator (Magnuson et al., 2000; Weyhenmeyer et al., 2011). Continuous and accurate monitoring of lake ice dynamics is greatly needed for studies of global change and for monitoring lake ice impacts on ecosystems and infrastructure, especially for high-latitude and high-altitude regions. In this study, we developed a new automated algorithm for consistent daily retrieval of lake ice conditions over the Northern Hemisphere using similar $36.5 \mathrm{GHz} \mathrm{H}$-polarized $T_{\mathrm{b}}$ observations from AMSR-E and AMSR2 sensor records. The resulting $5 \mathrm{~km}$ resolution lake ice phenology record allows for daily monitoring of lake ice conditions without being significantly degraded by variations in solar illumination or cloud and atmosphere contamination effects. In particular, the LIP record distinguished 71 large lakes that satisfied 20-day minimum ICDe and open water season algorithm thresholds; these lakes represent approximately $23 \%$ of the total surface area of large lakes $\left(\operatorname{area} \geq 50 \mathrm{~km}^{2}\right)$ within the Northern Hemisphere domain. Smaller water bodies were excluded from the lake-wide analysis if the lakes had no pixels with complete $(100 \%)$ open water coverage outside of a $5 \mathrm{~km}$ land buffer zone. The relatively coarse spatial resolution of AMSR-E/2 observations limits capabilities for resolving finer-scale water bodies, while the conservative lake selection criterion minimizes potential land contamination effects. The LIPderived lake ice conditions were found to be largely consistent with GLRIPD ground-based observations, with an average agreement of $95.4 \%$ for the four lakes examined. The LIP record also showed favorable correspondence with other lake CFO and WCI assessments defined from the CIS and IMS products for 12 large study lakes. The LIP, CIS, and IMS differences were attributed to the different data sources and methods used to construct the different products, including differences in spatial and temporal resolutions of observations, and distinct nature of optical and microwave remote sensing. Though the design of the LIP algorithm, including the MTT method, helps to identify lake breakup/freeze-up events, while minimizing other $T_{\mathrm{b}}$ disturbances from shortterm weather events, atmosphere effects can still lead to retrieval errors, especially from persistent high atmosphere water vapor concentrations over high-latitude lakes in the summer. Based on the LIP record from 2002 to 2015, significant earlier melting of lake ice cover was detected for 5 of the 71 lakes examined in the Northern Hemisphere, while lakes at higher latitudes show a more evident warming trend toward earlier ice breakup and shorter ICDe than those at lower latitudes. As the operations from AMSR2 and similar sensors continue, the MTT algorithm will allow for automated retrieval and consistent monitoring of ice conditions for large Northern Hemisphere lakes into the future.

\section{Data availability}

The AMSR-E/2 derived Northern Hemisphere LIP record described in this study is publicly available through the following link http://files.ntsg.umt.edu/data/AMSRE2_LAKE_ ICE_PHEN (Du et al., 2017). 


\section{Appendix A: List of Abbreviations and Acronyms}

\begin{tabular}{ll} 
AMSR2 & Advanced Microwave Scanning Radiometer 2 \\
AMSR-E & Advanced Microwave Scanning Radiometer for EOS \\
AMSR-E/2 & Advanced Microwave Scanning Radiometer for EOS and Advanced Microwave Scanning Radiometer 2 \\
AMSU & Advanced Microwave Sounding Unit \\
AVHRR & Advanced Very High Resolution Radiometer \\
CFO & complete freeze over \\
CIS & Canadian Ice Service \\
ERA-Interim & a global atmospheric model data reanalysis produced by the European Centre for Medium-Range \\
& Weather Forecasts \\
GBL & Great Bear Lake \\
GLRIPD & Global Lake and River Ice Phenology Database \\
GLWD & Global Lakes and Wetlands Database \\
GOES & Geostationary Operational Environmental Satellite \\
GSL & Great Slave Lake \\
IMS & Interactive Multisensor Snow and Ice Mapping System \\
LST & land surface temperature \\
MODIS & Moderate Resolution Imaging Spectroradiometer \\
MOD44W & MODIS 250 m land-water mask \\
MTT & moving $t$ test method \\
PFCs & perfluorinated chemicals \\
$R$ & correlation coefficient \\
RFI & radio frequency interference \\
SAT & surface air temperature \\
SMMR & Scanning Multichannel Microwave Radiometer \\
SSM/I & Special Sensor Microwave Imager \\
$T_{\mathrm{b}}$ & brightness temperature \\
TIR & thermal infrared \\
VIIRS & Visible/Infrared Imaging Radiometer Suite \\
WCI & water clear of ice \\
\hline
\end{tabular}


Acknowledgements. AMSR-E data are produced by Remote Sensing Systems and sponsored by the NASA Earth Science MEaSUREs DISCOVER Project and the AMSR-E Science Team. Data are available at http://www.remss.com. AMSR-E data and land cover classification maps were also provided courtesy of the National Snow and Ice Data Center (NSIDC). The AMSR2 L1R $T_{\mathrm{b}}$ data used for this study were provided courtesy of JAXA. The Global Lakes and Wetlands Database is provided by the World Wildlife organization and created by the Center for Environmental Systems Research, University of Kassel, Germany. This work was conducted at the University of Montana with funding from NASA (NNX15AT74A).

Edited by: R. Brown

Reviewed by: two anonymous referees

\section{References}

Ashcroft, P. and Wentz, F.: Algorithm Theoretical Basis Document, AMSR level 2A algorithm, Tech. Rep, Remote Sens. Syst, Santa Rosa, CA, 27 pp., 2000.

Bengtsson, L. and Herschy, R. W.: Encyclopedia of lakes and reservoirs, Monog. Biol., 53, 10-26, 2012.

Benson, B. J. and Magnuson, J. J.: Global Lake and River Ice Phenology Database, Version 1, NSIDC: National Snow and Ice Data Center, Boulder, Colorado USA, doi:10.7265/N5W66HP8, 2000 (updated 2012).

Benson, B. J., Magnuson, J. J., Jensen, O. P., Card, V. M., Hodgkins, G., Korhonen, J., Livingstone, D. M., Stewart, K. M., Weyhenmeyer, G. A., and Granin, N. G.: Extreme events, trends, and variability in Northern Hemisphere lake-ice phenology (18552005), Climatic Change, 112, 299-323, doi:10.1007/s10584011-0212-8, 2012.

Brodzik, M. J., Billingsley, B., Haran, T., Raup, B., and Savoie, M. H.: EASE-Grid 2.0: Incremental but Significant Improvements for Earth-Gridded Data Sets, ISPRS Int. J. Geo-Inform., 1, 3245, doi:10.3390/ijgi1010032, 2012.

Brodzik, M. J., Billingsley, B., Haran, T., Raup, B., and Savoie, M. H.: Correction: Brodzik, M. J. et al.: EASE-Grid 2.0: Incremental but Significant Improvements for Earth-Gridded Data Sets, ISPRS Int. J. Geo-Inform. 3, 1154-1156, doi:10.3390/ijgi3031154, 2014.

Brown, L. C. and Duguay, C. R.: Modelling lake ice phenology with an examination of satellite-detected subgrid cell variability, Adv. Meteorol., 2012, 1-19, doi:10.1155/2012/529064, 2012.

Brown, L. C., Howell, S. E., Mortin, J., and Derksen, C.: Evaluation of the Interactive Multisensor Snow and Ice Mapping System (IMS) for monitoring sea ice phenology, Remote Sens. Environ., 147, 65-78, 2014.

Carroll, M., Townshend, J., DiMiceli, C., Noojipady, P., and Sohlberg, R.: A New Global Raster Water Mask at 250 Meter Resolution, Int. J. Digital Earth, 2, 291-308, 2009.

Chang, A. T. C., Foster, J. L., Hall, D. K., Goodison, B. E., Walker, A. E., Metcalfe, J. R., and Harby, A.: Snow parameters derived from microwave measurements during the BOREAS winter field campaign, J. Geophys. Res.-Atmos., 102, 29663-29671, 1997.
Che, T., Li, X., and Jin, R.: Monitoring the frozen duration of Qinghai Lake using satellite passive microwave remote sensing low frequency data, Chinese Sci. Bull., 54, 2294-2299, 2009.

Chu, T. and Lindenschmidt, K. E.: Integration of space-borne and air-borne data in monitoring river ice processes in the Slave River, Canada, Remote Sens. Environ., 181, 65-81, 2016.

Dee, D. P., Uppala, S. M., Simmons, A. J., Berrisford, P., Poli, P., Kobayashi, S., Andrae, U., Balmasewda, M. A., Balsamo, G., Bauer, P., Bechtold, P., Beljaars, A. C. M., van de Berg, L., Bidlot, J., Bormann, N., Delsol, C., Dragani, R., Fuentes, M., Geer, A. J., Haimberger, L., Healy, S. B., Hersbach, H., Holm, E. V., Isaksen, L., Kallberg, P., Kohler, M., Matricardi, M., McNally, A. P., Monge-Sanz ,B. M., Morcrette, J. J., Park, B. K., Peubey, C., de Rosnay, P., Tavolato, C., Thepaut, J. N., and Vitart, F.: The ERA-Interim reanalysis: configuration and performance of the data assimilation system, Q. J. Roy. Meteor. Soc., 137, 553-597, 2011.

Deutsch, C. A., Tewksbury, J. J., Huey, R. B., Sheldon, K. S., Ghalambor, C. K., Haak, D. C., and Martin, P. R.: Impacts of climate warming on terrestrial ectotherms across latitude, P. Natl. Acad. Sci. USA, 105, 6668-6672, 2008

Du, J., Shi, J., and Rott, H.: Comparison between a multi-scattering and multi-layer snow scattering model and its parameterized snow backscattering model, Remote Sens. Environ., 114, 10891098, 2010.

Du, J., Kimball, J. S., Shi, J., Jones, L. A., Wu, S., Sun, R., and Yang, H.: Inter-calibration of satellite passive microwave land observations from AMSR-E and AMSR2 using overlapping FY3B-MWRI sensor measurements, Remote Sens., 6, 85948616, 2014.

Du, J., Kimball, J. S., and Jones, L. A.: Satellite microwave retrieval of total precipitable water vapor and surface air temperature over land from AMSR2, IEEE T. Geosci. Remote Sens., 53, 25202531, 2015.

Du, J., Kimball, J. S., Jones, L. A., and Watts, J. D.: Implementation of satellite based fractional water cover indices in the pan-Arctic region using AMSR-E and MODIS, Remote Sens. Environ., 184, 469-481, 2016.

Du, J., Kimball, J. S., and Duguay, C.: Daily Lake Ice Phenology Data Record Time Series Derived from AMSR-E and AMSR2, Version 1 (2002-2015), Missoula, Montana USA, Numerical Terradynamic Simulation Group, University of Montana, available at: http://files.ntsg.umt.edu/data/AMSRE2 LAKE_ICE_PHEN, last access: 10 January 2017.

Duguay, C. R., Prowse, T. D., Bonsal, B. R., Brown, R. D., Lacroix, M. P., and Ménard, P.: Recent trends in Canadian lake ice cover, Hydrol. Process., 20, 781-801, 2006.

Duguay, C. R., Brown, L., Kang, K. K., and Kheyrollah Pour, H.: Lake ice, in: State of the Climate in 2011, B. Am. Meteorol. Soc., 93, S152-S154, 2012.

Duguay, C. R., Brown, L., Kang, K. K., and Kheyrollah Pour, H.: Lake ice, in: State of the Climate in 2012, B. Am. Meteorol. Soc., 94, S124-S126, 2013.

Duguay, C. R., Brown, L., Kang, K. K., and Kheyrollah Pour, H.: Lake ice, in: State of the Climate in 2013, B. Am. Meteorol. Soc., 95, S138-S139, 2014.

Duguay, C. R., Bernier, M., Gauthier, Y., and Kouraev, A.: Remote sensing of lake and river ice, in: Remote Sensing of the 
Cryosphere, edited by: Tedesco, M., Wiley-Blackwell (Oxford, UK), 273-306, 2015a.

Duguay, C. R., Brown, L., Kang, K. K., and Kheyrollah Pour, H.: Lake ice, in: State of the Climate in 2014, B. Am. Meteorol. Soc., 96, S144-S145, 2015b.

Ferraro, R. R., Grody, N. C., and Kogut, J. A.: Classification of geophysical parameters using passive microwave satellite measurements, IEEE T. Geosci. Remote Sens., 24, 1008-1013, 1986.

Geldsetzer, T., Sanden, J. V. D., and Brisco, B.: Monitoring lake ice during spring melt using RADARSAT-2 SAR, Can. J. Remote Sens., 36, S391-S400, 2010.

Greene, S., Walter Anthony, K. M., Archer, D., Sepulveda-Jauregui, A., and Martinez-Cruz, K.: Modeling the impediment of methane ebullition bubbles by seasonal lake ice, Biogeosciences, 11, 6791-6811, doi:10.5194/bg-11-6791-2014, 2014.

Hall, D. K., Foster, J. L., Chang, A. T., and Rango, A., Freshwater ice thickness observations using passive microwave sensors, IEEE T. Geosci. Remote Sens., 4, 189-193, 1981.

Hall, D. K., Riggs, G. A., Foster, J. L., and Kumar, S. V.: Development and evaluation of a cloud-gap-filled MODIS daily snowcover product, Remote Sens. Environ., 114, 496-503, 2010.

Helfrich, S. R., McNamara, D., Ramsay, B. H., Baldwin, T., and Kasheta, T.: Enhancements to, and forthcoming developments in the Interactive Multisensor Snow and Ice Mapping System (IMS), Hydrol. Process., 21, 1576-1586, 2007.

Howell, S. E., Brown, L. C., Kang, K. K., and Duguay, C. R.: Variability in ice phenology on Great Bear Lake and Great Slave Lake, Northwest Territories, Canada, from SeaWinds/QuikSCAT: 2000-2006, Remote Sens. Environ., 113, 816-834, doi:10.1016/j.rse.2008.12.007, 2009.

Imaoka, K., Kachi, M., Kasahara, M., Ito, N., Nakagawa, K., and Oki, T.: Instrument performance and calibration of AMSR-E and AMSR2, ISPRS Archives, 38, 13-18, 2010.

Jeffries, M. O., Morris, K., and Kozlenko, N.: Ice characteristics and processes, and remote sensing of frozen rivers and lakes in remote sensing, in: Northern hydrology: Measuring environmental change, edited by: Duguay, C. R. and Pietroniro, A., Geophysical Monograph 163, American Geophysical Union, 63-90, 2005.

Jiang, J. M. and You, X. T.: Where and when did an abrupt climatic change occur in China during the last 43 years?, Theor. Appl. Climatol., 55, 33-40, 1996.

Kang, K.-K., Duguay, C. R., and Howell, S. E. L.: Estimating ice phenology on large northern lakes from AMSR-E: algorithm development and application to Great Bear Lake and Great Slave Lake, Canada, The Cryosphere, 6, 235-254, doi:10.5194/tc-6235-2012, 2012.

Kang, K. K., Duguay, C. R., Lemmetyinen, J., and Gel, Y.: Estimation of ice thickness on large northern lakes from AMSRE brightness temperature measurements, Remote Sens. Environ., 150, 1-19, 2014.

Karetnikov, S. G. and Naumenko, M. A.: Recent trends in Lake Ladoga ice cover, Hydrobiologia, 599, 41-48, 2008.

Kawanishi, T. J., Sezai, T., Ito, Y., Imaoka, K., Takeshima, T., Ishido, Y., Shibata, A., Miura, M., Inahata, H., and Spencer, R. W.: The Advanced Scanning Microwave Radiometer for the EarthObserving System (AMSR-E): NASDA's contribution to the EOS for global energy andwater cycle studies, IEEE T. Geosci. Remote Sens., 41, 184-194, 2003.
Ke, C. Q., Tao, A. Q., and Jin, X.: Variability in the ice phenology of Nam Co Lake in central Tibet from scanning multichannel microwave radiometer and special sensor microwave/imager: 1978 to 2013, J. Appl. Remote Sens., 7, 073477, doi:10.1117/1.JRS.7.073477, 2013.

Kheyrollah Pour, K., Duguay, C. R., Martynov, A., and Brown, L. C.: Simulation of surface temperature and ice cover of large northern lakes with 1-D models: A comparison with MODIS satellite data and in situ measurements, Tellus A, 64, 17614, doi:10.3402/tellusa.v64i0.17614, 2012.

Kim, Y., Kimball, J. S., Zhang, K., and McDonald, K. C.: Satellite detection of increasing Northern Hemisphere non-frozen seasons from 1979 to 2008: Implications for regional vegetation growth, Remote Sens. Environ., 121, 472-487, 2012.

Kouraev, A. V., Semovski, S. V., Shimaraev, M. N., Mognard, N. M., Légresy, B., and Remy, F.: Observations of Lake Baikal ice from satellite altimetry and radiometry, Remote Sens. Environ., 108, 240-53, 2007a.

Kouraev, A. V., Semovski, S. V., Shimaraev, M. N., Mognard, N. M., Légresy, B., and Remy, F.: The ice regime of Lake Baikal from historical and satellite data: Relationship to air temperature, dynamical, and other factors, Limnol. Oceanogr., 52, 1268-1286, 2007b.

Latifovic, R. and Pouliot, D.: Analysis of climate change impacts on lake ice phenology in Canada using the historical satellite data record, Remote Sens. Environ., 106, 492-507, 2007.

Leconte, R. and Klassen, P. D.: Lake and river ice investigations in northern Manitoba using airborne SAR imagery, Arctic, 44, 153-163, 1991.

Lehner, B. and Döll, P.: Development and validation of a global database of lakes, reservoirs and wetlands, J. Hydrol., 296, 1-22, 2004.

Lemmetyinen, J., Pulliainen, J., Rees, A., Kontu, A., Qiu, Y., and Derksen, C.: Multiple-layer adaptation of HUT snow emission model: Comparison with experimental data, IEEE T. Geosci. Remote Sens., 48, 2781-2794, 2010.

Lemmetyinen, J., Kontu, A., Kärnä, J. P., Vehviläinen, J., Takala, M., and Pulliainen, J.: Correcting for the influence of frozen lakes in satellite microwave radiometer observations through application of a microwave emission model, Remote Sens. Environ., 115, 3695-3706, 2011.

Livingstone, D. M.: Break-up dates of Alpine lakes as proxy data for local and regional mean surface air temperatures, Climatic Change, 37, 407-439, 1997.

Maeda, T., Taniguchi, Y., and Imaoka, K.: GCOM-W1 AMSR2 Level 1R Product: Dataset of Brightness Temperature Modified Using the Antenna Pattern Matching Technique, IEEE T. Geosci. Remote Sens., 54, 770-782, 2016.

Magnuson, J. J., Robertson, D. M., Benson, B. J., Wynne, R. H., Livingstone, D. M., Arai, T., Assel, R. A., Barry, R. G., Card, V., Kuusisto, E., and Granin, N. G.: Historical trends in lake and river ice cover in the Northern Hemisphere, Science, 289, 17431746, 2000.

Maslanik, J. A. and Barry, R. G.: Lake ice formation and breakup as an indicator of climate change: Potential for monitoring using remote sensing techniques, The Influence of Climate Change and Climatic Variability on the Hydrologic Regime and Water Resources, International Association of Hydrological Sciences Press, IAHS Publ. No. 168, 153-161, 1987. 
Mätzler, C.: Passive microwave signatures of landscapes in winter, Meteorol. Atmos. Phys., 54, 241-260, 1994.

Ménard, P., Duguay, C. R., Flato, G. M., and Rouse, W. R.: Simulation of ice phenology on Great Slave Lake, Northwest Territories, Canada, Hydrol. Process., 16, 3691-3706, 2002.

Mishra, V., Cherkauer, K. A., Bowling, L. C., and Huber, M.: Lake Ice phenology of small lakes: Impacts of climate variability in the Great Lakes region, Glob. Planet. Change, 76, 166-185, 2011.

Mountain Research Initiative EDW Working Group: Elevationdependent warming in mountain regions of the world, Nat. Clim. Change, 5, 424-430, 2015.

Noguchi, K., Gel, Y. R., and Duguay, C. R.: Bootstrap-based tests for trends in hydrological time series, with application to ice phenology data, J. Hydrol., 410, 150-161, 2011.

Nolan, M., Liston, G., Prokein, P., Brigham-Grette, J., Sharpton, V. L., and Huntzinger, R.: Analysis of lake ice dynamics and morphology on Lake El'gygytgyn, NE Siberia, using synthetic aperture radar (SAR) and Landsat, J. Geophys. Res.-Atmos., 107, 000934, doi:10.1029/2001JD000934, 2002.

Nonaka, T., Matsunaga, T., and Hoyano, A.: Estimating ice breakup dates on Eurasian lakes using water temperature trends and threshold surface temperatures derived from MODIS data, Int. J. Remote Sens., 28, 2163-2179, doi:10.1080/01431160500391957, 2007.

Park, H., Yoshikawa, Y., Oshima, K., Kim, Y., Ngo-Duc, T., Kimball, J. S., and Yang, D.: Quantification of Warming ClimateInduced Changes in Terrestrial Arctic River Ice Thickness and Phenology, J. Climate, 29, 1733-1754, 2016.

Prowse, T., Alfredsen, K., Beltaos, S., Bonsal, B., Duguay, C., Korhola, A., McNamara, J., Pienitz, R., Vincent, W. F., Vuglinsky, V., and Weyhenmeyer, G. A.: Past and future changes in Arctic lake and river ice, Ambio, 40, 53-62, 2011.

Schröter, D., Cramer, W., Leemans, R., Prentice, I. C., Araújo, M. B., Arnell, N. W., Bondeau, A., Bugmann, H., Carter, T. R., Gracia, C. A., and Anne, C.: Ecosystem service supply and vulnerability to global change in Europe, Science, 310, 1333-1337, 2005.

Sen, P. K.: Estimates of the Regression Coefficient Based on Kendall's Tau, J. Am. Stat. Assoc., 63, 1379-1389, 1968.

Serreze, M. C. and Francis, J. A.: The Arctic amplification debate, Climatic Change, 76, 241-264, 2006.

Solomon, S., Qin, D., Manning, M., Chen, Z., Marquis, M., Averyt, K. B., Tignor, M., and Mill, H. L. (Eds.): Climate Change 2007: The Physical Science Basis, Cambridge University Press, Cambridge, United Kingdom and New York, NY, USA, 2007.

Stocker, T. F., Qin, D., Plattner, G.-K., Tignor, M., Allen, S. K., Boschung, J., Nauels, A., Xia, Y., Bex, V., and Midgley, P. M.: IPCC, 2013: Climate Change 2013: The Physical Science Basis. Contribution of Working Group I to the Fifth Assessment Report of the Intergovernmental Panel on Climate Change, Cambridge University Press, Cambridge, United Kingdom and New York, NY, USA, 2013.
Surdyk, S.: Using microwave brightness temperature to detect short-term surface air temperature changes in Antarctica: An analytical approach, Remote Sens. Environ., 80, 256-271, 2002.

Ulaby, F. T., Moore, R. K., and Fung, A. K.: Microwave Remote Sensing: Active and Passive, Volume III: from Theory to Applications, Artech House, Norwood, MA, USA, 1986.

Veillette, J., Muir, D. C., Antoniades, D., Small, J. M., Spencer, C., Loewen, T. N., Babaluk, J. A., Reist, J. D., and Vincent, W. F.: Perfluorinated chemicals in meromictic lakes on the northern coast of Ellesmere Island, High Arctic Canada, Arctic, 65, 245256, 2012.

Vuglinsky, V. S. and Gronskaya, T. P.: Changing of rivers and lakes ice regime within the Russian territory and their possible consequences for economy, Modern problems of hydrometeorology, 229245, 229-245, 2006.

Walker, A. E. and Davey, M. R.: Observation of Great Slave Lake ice freeze-up and break-up processes using passive microwave satellite data, in: Proceedings of the 16th Canadian Symposium on Remote Sensing, June 1993, Sherbrooke, QC, Canada, 233238, 1993.

Wang, G., Bai, W., Li, N., and Hu, H.: Climate changes and its impact on tundra ecosystem in Qinghai-Tibet Plateau, China, Climatic Change, 106, 463-482, 2011.

Wang, J. R. and Tedesco, M.: Identification of atmospheric influences on the estimation of snow water equivalent from AMSR-E measurements, Remote Sens. Environ., 111, 398-408, 2007.

Weyhenmeyer, G. A., Livingstone, D. M., Meili, M., Jensen, O., Benson, B., and Magnuson, J. J.: Large geographical differences in the sensitivity of ice-covered lakes and rivers in the Northern Hemisphere to temperature changes, Glob. Chang. Biol., 17, 268-275, 2011.

Woo, M. K., Modeste, P., Martz, L., Blondin, J., Kochtubajda, B., Tutcho, D., Gyakum, J., Takazo, A., Spence, C., Tutcho, J., Di Cenzo, P., Kenny, G., Stone, J., Neyelle, I., Baptiste, G., Modeste, M., Kenny, B., and Modeste, W.: Science meets traditional knowledge: water and climate in the Sahtu (Great Bear Lake) region, Northwest Territories, Canada, Arctic, 60, 37-46, 2007.

Wrona, F. J., Johansson, M., Culp, J. M., Jenkins, A., Mård, J., Myers-Smith, I. H., Prowse, T. D., Vincent, W. F., and Wookey, P. A.: Transitions in Arctic ecosystems: Ecological implications of a changing hydrological regime, J. Geophys. Res.-Biogeo., 121, 650-674, 2016.

Xiao, D. and Li, J.: Spatial and temporal characteristics of the decadal abrupt changes of global atmosphere-oceansystem in the 1970s, J. Geophys. Res.-Atmos., 112, D24S22, doi:10.1029/2007JD008956, 2007.

Zhang, X., Vincent, L. A., Hogg, W. D., and Niitsoo, A.: Temperature and precipitation trends in Canada during the 20th century, Atmos.-Ocean, 38, 395-429, 2000. 